\title{
Interaction of Nitric Oxide and Cyclic Guanosine 3',5'-Monophosphate in Erythropoietin Production
}

\author{
Takashi Ohigashi, Jesse Brookins, and James W. Fisher \\ Tulane University School of Medicine, Department of Pharmacology, New Orleans, Louisiana 70112
}

\begin{abstract}
The present study was designed to investigate whether in vivo and in vitro erythropoietin (EPO) production is modulated by nitric oxide (NO) and cyclic guanosine $3^{\prime}, 5^{\prime}$-monophosphate (cGMP). Serum levels of EPO in exhypoxic polycythemic mice were significantly increased after injections of $200 \mu \mathrm{g} / \mathrm{kg}$ sodium nitroprusside for $4 \mathrm{~d}$. One injection of $N^{\mathbf{G}}$-nitro-L-arginine methyl ester ( $L$-NAME) produced a significant dose-related decrease in serum levels of EPO in exhypoxic polycythemic mice in response to hypoxia. When EPO producing Hep3B cells were incubated in $1 \% \mathrm{O}_{2}$ for $30 \mathrm{~min}$, cGMP levels in the Hep3B cells were significantly elevated, compared with cells incubated in $20 \% \mathrm{O}_{2}$. The elevation of cGMP by hypoxia was inhibited by L-NAME ( $100 \mu M)$. Sodium nitropruside (10 and $100 \mu \mathrm{M})$ and NO $(2 \mu \mathrm{M})$ also significantly increased cGMP levels in Hep3B cells. L-NAME, LY 83583 (6-Anilino-5,8quinolinedione, a soluble guanylate cyclase inhibitor), and Rp8-Bromo-cGMPS (Rp-8-Bromo-guanosine 3',5'-cyclic monophosphothioate, a cGMP-dependent protein kinase inhibitor) significantly inhibited the hypoxia-induced increase in medium levels of EPO in Hep3B cells. 8-Bromo-cGMPS produced a dose-dependent decrease in EPO messenger RNA levels in Hep3B cells in response to hypoxia. 8-Bromo-cGMP $\left(10^{-3} \mathrm{M}\right)$ produced significant increases in medium levels of EPO in Hep3B cell cultures incubated under normoxic conditions, which was enhanced by the phosphodiesterase inhibitor, 3-isobutyl-1-methylxanthine $(0.2 \mathrm{mM})$. These results suggest that NO and cGMP may interact in modulating hypoxic stimulation of EPO production. (J. Clin. Invest. 1993.92:1587-1591.) Key words: nitroprusside $\bullet$ protein kinase $\bullet$ messenger RNA
\end{abstract}

\section{Introduction}

Erythropoietin (EPO) ${ }^{1}$ is a glycoprotein produced primarily by the adult kidney and by the liver of the fetus and anephric

Address correspondence to James W. Fisher, Ph.D., Tulane University School of Medicine, Department of Pharmacology, 1430 Tulane Avenue, New Orleans, LA 70112.

Received for publication 11 March 1993 and in revised form 15 June 1993.

1. Abbreviations used in this paper: EHPCM, exhypoxic polycythemic mice; EPO, erythropoietin; Hep3B, human cloned hepatocellular carci-

J. Clin. Invest.

(c) The American Society for Clinical Investigation, Inc.

0021-9738/93/09/1587/05 \$2.00

Volume 92, September 1993, 1587-1591 subject (1). EPO causes an orderly increase in the proliferation and differentiation of erythroid progenitor cells in the bone marrow (1). Hypoxia is well known to be the fundamental stimulus for EPO production both in vivo (2) and in vitro (3). However, the oxygen sensing mechanism in EPO production is still not clearly understood. Pohl and Busse reported that a reduction in the partial pressure of oxygen stimulated the release of endothelium-derived relaxant factor from native and cultured endothelial cells (4). Nitric oxide (NO), which has been established to be endothelium-derived relaxant factor (5), stimulates soluble guanylate cyclase (SGC) to increase cGMP levels in cells (6). NO is rapidly inactivated by contact with hemoglobin or superoxide produced under hyperoxic conditions (5). NO was recently reported to mediate biological processes, not only in vascular endothelial cells, but in a variety of other tissues, including brain, blood cells (6), liver (7), and kidney (8). The purpose of the present studies was to determine whether there is a relationship between the interaction of NO and CGMP in EPO production in vivo in exhypoxic polycythemic mice and in vitro in our EPO producing Hep3B cell culture system.

\section{Methods}

Chemicals. All chemicals were purchased from Sigma Chemical Company (St. Louis, MO), with the exception of those specifically described.

Exhypoxic polycythemic mice (EHPCM). The details of the methods used in these studies have been described previously (9). Briefly, CD-1 strain female mice were made polycythemic by 22 -h daily exposure to $0.42 \mathrm{~atm}$ of ambient air pressure for $2 \mathrm{wk}$. In the sodium nitroprusside (SNP) group, several concentrations of SNP in 5\% glucose solution were injected intravenously as single doses in a $0.2-\mathrm{ml}$ vol on posthypoxic days $3,4,5$, and $6 . \mathrm{N}^{\mathrm{G}}$-nitro-L-arginine methyl ester ( $\mathrm{L}$ NAME) was administered as a single injection on the 6th posthypoxic day. In both groups, mice were exposed to a reduced atmospheric pressure $(0.42 \mathrm{~atm})$ for $4 \mathrm{~h}$ on the 6th posthypoxic day. After hypobaric stimulation, the mice were immediately anesthetized with ether and exsanguinated via cardiac puncture. Blood samples were allowed to clot at $4^{\circ} \mathrm{C}$, and the serum was separated by centrifugation. EPO levels in the serum were determined by a sensitive RIA. The details of the RIA used in our laboratory have been published previously (10).

cGMP determinations in hepatocellular carcinoma cells. Human hepatocellular carcinoma cells (Hep3B) were carried in a monolayer cell culture and maintained in Eagle's minimal essential medium supplemented with $10 \%$ FBS, $0.1 \mathrm{mM}$ nonessential amino acids, $1 \mathrm{mM}$ sodium pyruvate, $100 \mathrm{U} / \mathrm{ml}$ penicillin $\mathrm{G}$, and $100 \mu \mathrm{g} / \mathrm{ml}$ streptomycin

noma cells; IBMX, 3-isobutyl-1-methylxanthine; L-NAME, $\mathrm{N}^{\mathrm{G}}$-nitroL-arginine methyl ester; LY 83583, 6-Anilino-5,8-quinolinedione; NO, nitric oxide; Rp-8-Bromo-cGMPS, Rp-8-Bromo-3',5' cyclic monophosphothioate; SNP, sodium nitroprusside. 
in a humidified atmosphere of $5 \% \mathrm{CO}_{2} / 95 \%$ air at $37^{\circ} \mathrm{C}$. Medium and supplements were purchased from Life Technologies, Inc. (Grand Island, NY). Determinations of CGMP were performed via radioimmunoassay according to a modification of the procedure described previously by Ueno et al. (11). Aliquots of $8.0 \times 10^{5}$ cells were dispensed into 12 multi-well plates. After 24-h preincubation, the cells were washed twice with PBS and then incubated in $1.0 \mathrm{ml}$ of serum free medium for $2 \mathrm{~min}$ with $\mathrm{NO}$ gas solution $(2 \mu \mathrm{M})$, for $10 \mathrm{~min}$ with SNP $\left(10\right.$ and $100 \mu \mathrm{M}$ ), or for $30 \mathrm{~min}$ in $1 \% \mathrm{O}_{2}$. The medium had been equilibrated for $2 \mathrm{~h}$ by bubbling with $5 \% \mathrm{CO}_{2} / 95 \% \mathrm{~N}_{2}$ before the NO gas experiments and $1 \% \mathrm{O}_{2} / 5 \% \mathrm{CO}_{2} / 94 \% \mathrm{~N}_{2}$ before the hypoxia experiments. No solutions were prepared by first bubbling $10 \mathrm{ml}$ of reagent grade methanol (EM Industries, Inc., Cherry Hill, NJ) for $20 \mathrm{~min}$ with nitrogen in a gas-tight reaction vial to remove dissolved oxygen. The methanol was then bubbled with NO gas (Hydrocarbon Technologies, Inc., Sulphur, LA) for $20 \mathrm{~min}$ and stored in a freezer in a gas-tight vial. The concentration of NO was measured with a nitric oxide analyzer (model 270; Sieves Research Inc., Boulder, CO) (12) and ranged from 30-50 mM. NO solutions were directly added to the medium. 100 $\mathrm{U} / \mathrm{ml}$ of superoxide dismutase was also added with the NO gas to prolong the half-life of NO. When the incubation was finished, the medium was aspirated, and $2.0 \mathrm{ml}$ of ice-cold $6 \%$ TCA was added. After centrifugation of the Hep3B cell extracts at $2,000 \mathrm{~g}$ for $20 \mathrm{~min}$, TCA was removed from the supernatant by repeated extraction with water-saturated ether. The lyophilized samples were resuspended in $0.05 \mathrm{M}$ sodium acetate buffer, and CGMP was measured by RIA using cGMP assay kits (DuPont, Boston, MA).

Inhibition of EPO production in Hep3B cells exposed to hypoxia. Three different inhibitors that act in the CGMP/NO system were used: L-NAME, which is an inhibitor of NO synthase; LY 83583 (6-anilino5,8-quinolinedione; Research Biochemical Inc., Natrick, MA), an inhibitor of soluble guanylate cyclase (13); and Rp-8-Bromo-cGMPS (Rp-8-Bromo-3',5' cyclic monophosphothioate, BIOLOG Life Science Institute, La Jolla, CA), which selectively inhibits cGMP-dependent protein kinase by competing with cGMP (14). Aliquots of $2.0 \times 10^{5}$ viable cells were cultured in $24-w e l l$ multiwell plates. After $24-\mathrm{h}$ incubation, the cells were incubated with several concentrations of inhibitors in sealed incubator chambers, which were connected to a gas tank composed of a mixture of $1 \% \mathrm{O}_{2} / 5 \% \mathrm{CO}_{2} / 94 \% \mathrm{~N}_{2}$ for $18 \mathrm{~h}$. The medium levels of EPO were assayed via a sensitive RIA (10).

cGMP-dependent protein kinase inhibition and EPO messenger RNA expression in Hep3B cells: For the determination of messenger RNA levels, Hep 3B cells were incubated either under normoxic (20\% $\left.\mathrm{O}_{2}\right)$ or hypoxic $\left(1 \% \mathrm{O}_{2}\right)$ conditions in the presence or absence of Rp-8Bromo-cGMPS. $10 \mu \mathrm{g}$ of RNA was spotted on a nitrocellulose membrane using a slot blot apparatus (Life Technologies, Inc.). The membranes were hybridized with ${ }^{32} \mathrm{P}$-labeled human EPO cDNA (gift from Dr. Jerry Powell) and B-actin cDNA (Clontech, Palo Alto, CA) for controls. The EPO mRNA levels were determined by autoradiography.

8-Bromo-cGMP and phosphodiesterase inhibition in EPO production in Hep3B cells. Aliquots of $2.0 \times 10^{5}$ viable cells were dispensed into 24-well multiwell plates, and the experiments were carried out after $24-\mathrm{h}$ preincubation. The cells were incubated with several concentrations of 8-Bromo-cGMP for $24 \mathrm{~h}$. Some experiments were carried out in the presence of 3-isobutyl-1-methylxanthine (IBMX). Hep3B cells were also incubated in the presence or absence of IBMX under hypoxic conditions $\left(1 \% \mathrm{O}_{2}\right)$ for $24 \mathrm{~h}$. The spent culture medium was collected and frozen at $-80^{\circ} \mathrm{C}$ until assayed with our a EPO radioimmunoassay.

Duncan's multiple range test (15) was used for the comparison of the data in several groups, and $P<0.05$ was considered to be statistically significant.

\section{Results}

$4 \mathrm{~d}$ injection of SNP ( $200 \mu \mathrm{g} / \mathrm{kg}$ mouse per d $)$ produced significant increases in serum levels of EPO in EHPCM (71.3 \pm 11.0
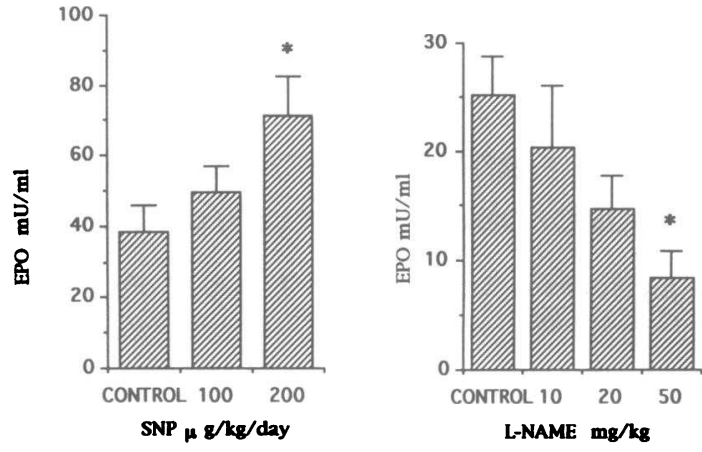

Figure 1. Effects of SNP and L-NAME on serum levels of EPO in EHPCM. Mice were injected with SNP for $4 \mathrm{~d}$ and L-NAME for $1 \mathrm{~d}$ intravenously. All mice were exposed to hypoxia for $4 \mathrm{~h}$ before being bled out. Each value represents the mean \pm SEM of eight $(S N P)$ and five ( $L-N A M E$ ) different experiments (five to eight mice per group in each experiment). (*) Indicates significantly different from the respective control $(P<0.05$, Duncan's multiple range test $)$.

$\mathrm{mU} / \mathrm{ml})$, compared with controls $(38.3 \pm 7.2 \mathrm{mU} / \mathrm{ml})$. On the other hand, an injection of L-NAME in a dosage of $50 \mathrm{mg} / \mathrm{kg}$ just before hypobaric hypoxic stimulation produced a significant decrease in serum levels of EPO $(8.4 \pm 2.4 \mathrm{mU} / \mathrm{ml})$ in response to hypoxia, when compared with hypoxic controls (25.1 $\pm 3.7 \mathrm{mU} / \mathrm{ml}$ ) (Fig. 1). Mean body weight and hematocrit were not significantly different between any of the groups throughout these in vivo studies.

When the Hep3B cells were incubated with authentic NO gas solution under conditions where no oxygen was present in the atmosphere $\left(5 \% \mathrm{CO}_{2}, 95 \% \mathrm{~N}_{2}\right)$ for $2 \mathrm{~min}$, cGMP levels were significantly elevated $\left(\mathrm{NO}=0.88 \pm 0.06 \mathrm{pmol} / 10^{6}\right.$ cells, controls $=0.36 \pm 0.03 \mathrm{pmol} / 10^{6}$ cells) (Fig. 2 ). SNP ( 10 and $100 \mu \mathrm{M})$ produced significant increases in cGMP levels in

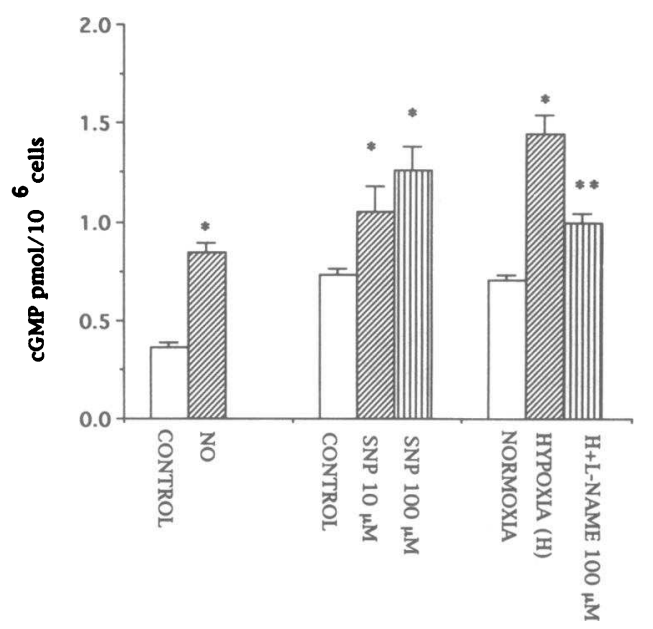

Figure 2. Effects of NO, SNP, and hypoxia on cGMP levels in Hep3B cells. Hep3B cells were incubated in $1 \mathrm{ml}$ of serum-free medium for 2 min with NO gas solution ( $2 \mu \mathrm{M}$ ), for 10 min with SNP ( 10 and $100 \mu \mathrm{M})$ in a normoxic (20\%) atmosphere, or for $30 \mathrm{~min}$ in $1 \% \mathrm{O}_{2}$ in the presence or absence of L-NAME $(100 \mu \mathrm{M})$. Each value represents the mean \pm SEM and the white bar indicates control for each group. (*) Indicates significantly different from the respective control, ** indicates significantly different from cells incubated in $1 \% \mathrm{O}_{2}$ without L-NAME. $(P<0.05$, unpaired $t$ test $)$. 


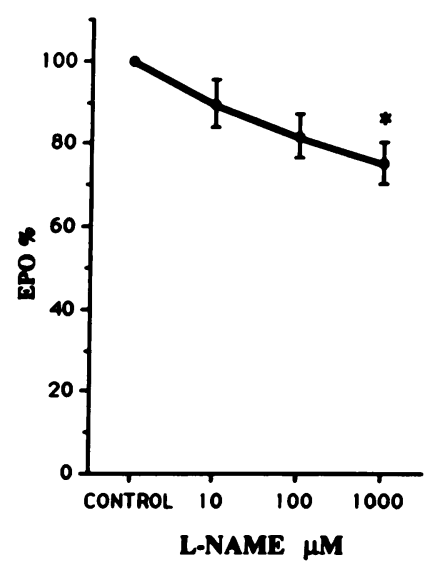

$\mathbf{A}$

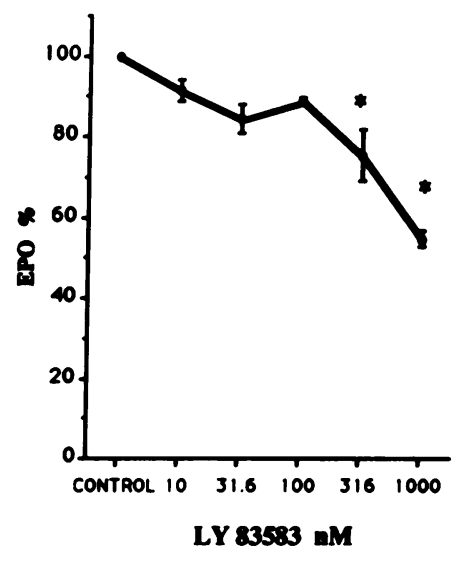

B
Hep3B cells $\left(1.05 \pm 0.13\right.$ and $1.26 \pm 0.12 \mathrm{pmol} / 10^{6}$ cells, respectively) after $10 \mathrm{~min}$ incubation in a normoxic atmosphere, compared with controls $\left(0.72 \pm 0.03 \mathrm{pmol} / 10^{6}\right.$ cells $)$. Hypoxic incubation of Hep3B cells for $30 \mathrm{~min}$ also increased cGMP levels significantly $\left(1.45 \pm 0.09 \mathrm{pmol} / 10^{6}\right.$ cells $)$, compared with normoxic controls $\left(0.71 \pm 0.02 \mathrm{pmol} / 10^{6}\right.$ cells $)$. L-NAME $(100 \mu \mathrm{M})$ significantly decreased cGMP levels in Hep3B cells $\left(0.99 \pm 0.05 \mathrm{pmol} / 10^{6}\right.$ cells $)$ when compared with cells treated with hypoxia alone.

L-NAME, LY 83583, and Rp-8-Bromo-cGMPS, all decreased EPO production in Hep3B cells exposed to hypoxia for $18 \mathrm{~h}$ in a dose-dependent manner (Fig. 3). L-NAME ( $1 \mathrm{mM}$ ), LY 83583 ( 316 and 1,000 nM), and Rp-8-Bromo-cGMPS ( 200 and $400 \mu \mathrm{M}$ ) produced significant decreases in medium levels of EPO in Hep3B cell cultures. None of the inhibitors produced any significant change in the viability of Hep3B cells
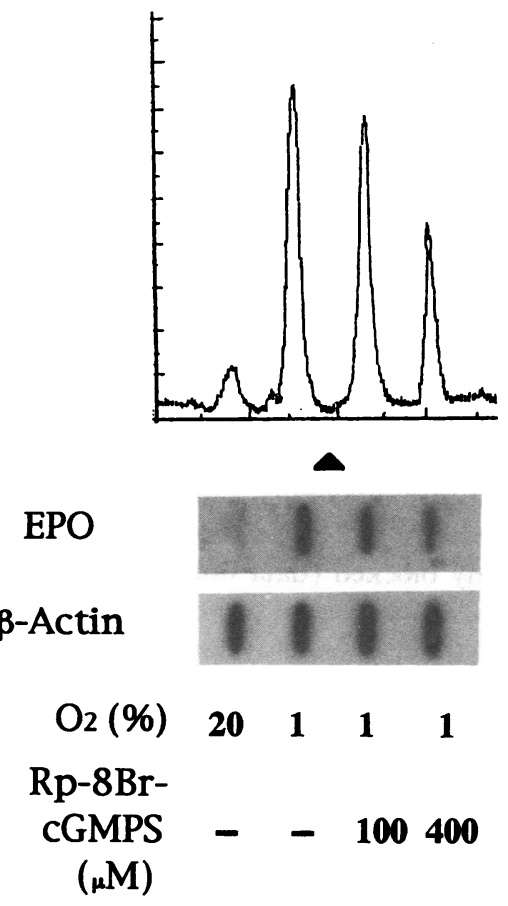

Figure 4. Effects of a selective cGMP dependent protein kinase inhibitor on mRNA levels in Hep3B cell cultures in response to hypoxia. Hep3B cells were incubated with Rp-8Bromo-cGMPS for $6 \mathrm{~h}$ in a hypoxic atmosphere $\left(1 \% \mathrm{O}_{2}\right)$ or in a normoxic atmosphere $(20 \%$ $\mathrm{O}_{2}$ ). Slot blot hybridization using a ${ }^{32} \mathrm{P}$-labeled probe is shown for a representative experiment. The densitometric tracings of the autoradiography of the slot blots are also shown at the top.

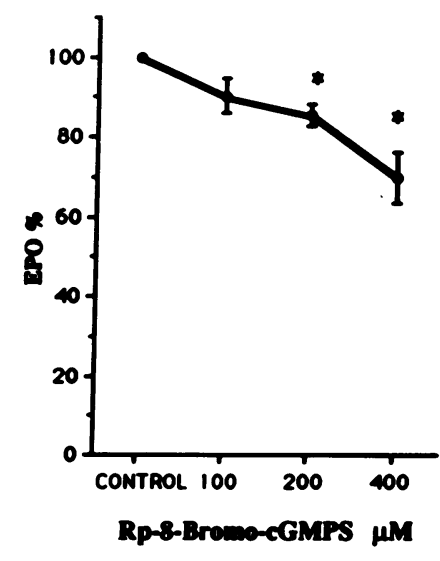

Figure 3. Effects of NO/ cGMP G-kinase inhibitors on medium levels of EPO in Hep3B cells exposed to hypoxia. Hep3B cells were incubated with L-NAME, LY 83583, or Rp-8-BromocGMPS for $18 \mathrm{~h}$ in a hypoxic atmosphere $\left(1 \% \mathrm{O}_{2}\right)$. Each value represents the mean \pm SEM of three ( $L$ NAME) and four (LY 83583, Rp-8-BromocGMPS) different experiments (six samples in each experiment $).(*)$ Indicates significantly different $(P$ $<0.05$, Duncan's multiple range test) from hypoxia controls (calculated from raw C data).

when drug sensitivity tests were carried out using a colorimetric [3 - (4,5 - dimethylthiazol - 2 - yl) - 2, 5 - diphenyltetrazolium (MTT)] assay (16).

Rp-8-Bromo-cGMPS also produced dose-dependent decreases in EPO mRNA levels in Hep3B cells after 6-h incubation under hypoxic conditions $\left(1 \% \mathrm{O}_{2}\right)$ (Fig. 4). $400 \mu \mathrm{M}$ of Rp-8-Bromo-cGMPS was required to decrease mRNA level in Hep3B cells to a level of 58\% of hypoxia controls using densitometry measurements of slot blot hybridization experiments.

When Hep3B cells were incubated for $24 \mathrm{~h}$ under normoxic conditions ( $5 \% \mathrm{CO}_{2} / 95 \%$ air ), 8-Bromo-cGMP at $10^{-3} \mathrm{M}$ produced a significant increase in medium levels of EPO $(4.27 \pm 0.34 \mathrm{mU} / \mathrm{ml})$, when compared with controls $(2.45 \pm 0.16 \mathrm{mU} / \mathrm{ml})$ (Fig. 5). In the presence of $10^{-4} \mathrm{M} 8$ Bromo-cGMP, IBMX $(0.02$ and $0.2 \mathrm{mM})$ significantly increased medium levels of EPO $(4.43 \pm 0.27 \mathrm{mU} / \mathrm{ml}$ and $8.42 \pm 0.89 \mathrm{mU} / \mathrm{m}$, respectively), compared with normoxic controls. IBMX $(0.2 \mathrm{mM})$ produced significant increases in medium levels of EPO when compared with Hep3B cells treated with 8-Bromo-cGMP alone $\left(10^{-4} \mathrm{M}\right)$. When hep3B cells were incubated under hypoxic conditions, IBMX (0.02 and $0.2 \mathrm{mM}$ ) also produced significant increases in medium EPO levels (88.5 \pm 5.1 and $130.6 \pm 2.8 \mathrm{mU} / \mathrm{ml}$, respectively), when compared with hypoxia controls $(73.7 \pm 0.7 \mathrm{mU} / \mathrm{ml})$.

\section{Discussion}

In the present experiments, we have shown that SNP, a generator of NO, produced a significant increase, and L-NAME, an NO synthase inhibitor, produced a significant decrease in serum levels of EPO in vivo in EHPCM. SNP is well known to generate $\mathrm{NO}$ in the presence of vascular tissue, hemoglobin, and plasma, or when irradiated with visible light (17). On the other hand, L-NAME inhibits NO synthase, which converts $\mathrm{L}$-arginine to L-citrulline and NO (18). These data suggest the possibility that NO may modulate EPO production in vivo. However, these experiments can not distinguish direct effects of NO on EPO producing cells in the kidney from the effects of NO on renal hemodynamic changes which could affect EPO production. Since NO has been reported to be EDRF (6), SNP has been demonstrated to produce vasodilation and a decrease in blood pressure in several experimental animals, while L- 


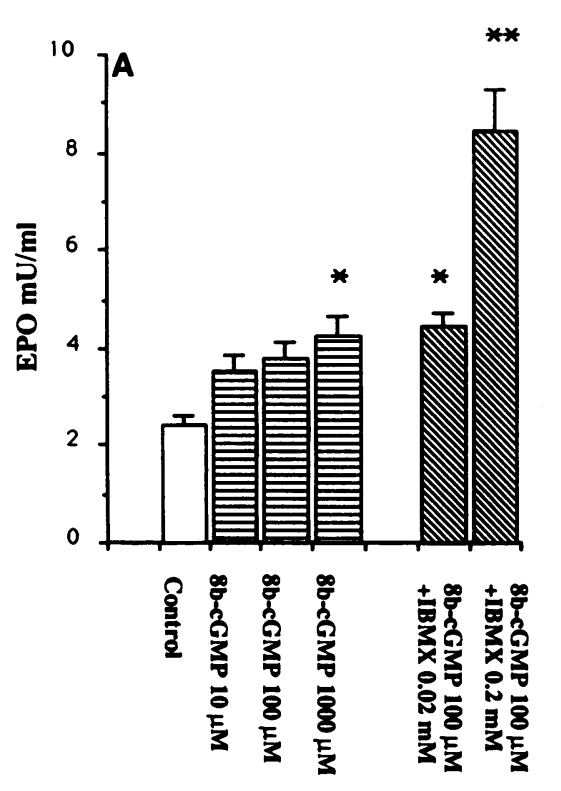

NAME produces vasoconstriction to increase blood pressure (17). We have reported previously that several vasoconstrictor agents increased EPO production in vivo or in isolated perfused kidneys through a reduction in renal blood flow (18). It has been reported that $\mathrm{N}^{\mathrm{G}}$-nitro-L-arginine produced significant decreases in renal perfusion flow rate in the isolated perfused rat kidney (20). Brezis et al. (21) also reported that L$\mathrm{N}^{\mathrm{G}}$-monomethyl-arginine, another NO synthase inhibitor, decreased renal medullary $\mathrm{PO}_{2}$ in rats, while increasing blood pressure and reducing renal blood flow. L-NAME probably reduces renal partial pressure of oxygen in the same manner. However, L-NAME produced a significant decrease in EPO production in the present experiments. Moreover, when we administered $200 \mu \mathrm{g} / \mathrm{kg}$ of SNP to rats in separate experiments, arterial blood pressure was reduced from 115 to 60 $\mathrm{mmHg}$ for $1 \mathrm{~min}$ and recovered within $30 \mathrm{~s}$ to $1 \mathrm{~min}$ (data not shown). Therefore, it is not likely that the effects of SNP are through renal hemodynamic changes, but is more likely a direct effect of NO on EPO producing cells in vivo.

A human cloned hepatocellular carcinoma cell line (Hep3B cells) has become an excellent model for the investigation of in vitro EPO production. When subconfluent Hep3B cells were exposed to hypoxia or treated with cobalt, a significant increase in both EPO secretion and expression of EPO messenger RNA was seen (3). Goldberg et al. (22) postulated that a heme protein is essential for EPO gene expression because hypoxia-induced EPO production by Hep3B cells was inhibited by carbon monoxide ( $\mathrm{CO}$ ), although this hypothetical protein has not yet been identified. The soluble form of guanylate cyclase (SGC) has a heme moiety in its structure, to which NO can bind (3). Binding of NO to heme results in SGC activation, which leads to cGMP generation. $\mathrm{CO}$ is also reported to activate SGC, but its potency in stimulating SGC is much weaker than NO (23). It was also recently reported that NO synthase itself has a heme moiety in its structure (24). Thus, it is possible that the NO/cGMP system could play a role in sensing oxygen in modulating EPO production.

In the present studies, authentic NO and SNP increased cGMP levels in Hep3B cells, which indicates that Hep3B cells have SGC, which can be stimulated by NO. The significant increase in cGMP seen in our Hep3B cell cultures in response to hypoxia is probably caused by the stimulation of endogenous NO synthesis. Although we have not confirmed the existence of NO synthase in Hep3B cells, it is quite likely that they contain NO synthase because normal liver cells have been reported to contain NO synthase (7). The inhibition of cGMP generation and EPO production in response to hypoxia by $\mathrm{L}-$ NAME suggests that NO synthesis is essential for hypoxic stimulation of EPO pathway.

All three inhibitors used in the present studies which interfered with the NO/cGMP cascade by different mechanisms decreased EPO production in Hep3B cells in response to hypoxia. These data strongly support our hypothesis that the NO/ cGMP system is involved in the EPO production pathway. LY 83583 has been considered to be an effective inhibitor of SGC, although the mechanism by which LY 83583 inhibits the generation of cGMP is still not well understood (13). Rp-8-BromocGMPS is a specific cGMP antagonist and only binds to the cGMP-binding sites of cGMP-dependent protein kinase (14). In our present experiments, Rp-8-Bromo-cGMPS also inhibited EPO mRNA expression in Hep3B cells exposed to hypoxia, which suggests that cGMP probably requires CGMP-dependent protein kinase to activate EPO gene expression. The inhibitory effects of L-NAME depended on competition with L-arginine, whereas Rp-8-Bromo-cGMPS competed with cGMP. The culture medium used in our experiments contained L-arginine ( $126 \mathrm{mg} /$ liter), whereas CGMP increased in Hep3B cells under hypoxic conditions. When we incubated Hep3B cells with another cGMP-dependent protein kinase inhibitor, H-8 ( $N$-[2-methylamino)ethyl]-5-isoquinolinesulfate), both hypoxia-induced EPO mRNA expression and EPO production were completely blocked (data not shown). H-8 has a higher affinity for cGMP-dependent protein kinase than any of the other protein kinases; however, it also binds to the active site of several other protein kinases in higher concentrations (25). Therefore, it is quite possible that hypoxia triggers other intracellular signals. Further work is necessary to clarify the role of other protein kinases in EPO production.

Our present data show that $10^{-3}$ M 8-Bromo-cGMP produced an almost twofold increase in EPO production in Hep3B 
cells under normoxic conditions, compared with controls. Although 8-Bromo-cGMP is hydrolyzed less rapidly by phosphodiesterase than native cGMP, a small amount of 8-BromocGMP is still hydrolyzed (26). IBMX is a nonselective phosphodiesterase inhibitor that interferes with the hydrolysis of both cGMP and cAMP. When IBMX was used in conjunction with 8-Bromo-cGMP or hypoxia, EPO production was significantly enhanced. We have reported previously that dibutyryl cAMP and activators of adenylate cyclase, such as forskolin or cholera toxin, enhance EPO production in Hep3B cells (23). However, the enhancement occurred only under hypoxic conditions. In a normoxic atmosphere, these compounds increased intracellular cAMP levels, but this was not accompanied by an elevation in culture medium levels of EPO (27). Hence, the enhanced EPO production by IBMX in our present studies is probably through the inhibition of cGMP hydrolysis. However, the increases in EPO production enhanced by 8Bromo-cGMP were much less than those produced by hypoxic stimulation or cobalt (27). Goldberg et al. (28) reported that hypoxia only produced a 10-fold increase in EPO gene transcription rate from nuclear run-off experiments, whereas steady-state EPO mRNA levels increased more than 50 -fold. They postulated that hypoxia acts not only on EPO gene expression, but also acts to stabilize EPO mRNA in the production of EPO in Hep3B cells. We propose that 8-Bromo-cGMP probably regulates EPO gene expression, and most likely does not affect the half-life of EPO mRNA because 8-Bromo-cGMP plus IBMX produced only a fourfold increase in EPO production in Hep3B cells.

In summary, the present studies demonstrate that NO and cGMP may play an interactive role in hypoxic regulation of EPO production.

\section{Acknowledgments}

The authors wish to thank Eugene Maulet for his technical assistance.

This study was supported by private funds. T. Ohigashi is a postdoctoral fellow from the Department of Urology, Keio University School of Medicine, Tokyo, Japan.

\section{References}

1. Fisher, J. W. 1992. Regulation of erythropoietin production. In Handbook of Physiology-Renal Physiology. E. E. Windhager, editor. Oxford University Press, New York. pp. 2407-2438.

2. Fisher, J. W. 1988. Pharmacologic modulation of erythro poietin production. Annu. Rev. Pharmacol. Toxicol. 28:101-122.

3. Goldberg, M. A., G. A. Glass, J. W. Cunningham, and H. F. Bunn. 1987. The regulated expression of erythropoietin by two human hepatoma cell line. Proc. Natl. Acad. Sci. USA. 84:7972-7976.

4. Pohl, U., and R. Busse. 1989. Hypoxia stimulates release of endotheliumderived relaxant factor. Am. J. Physiol. 256(Heart Circ. Physiol. 25):H159H1600.

5. Ignarro, L. J. 1989. Endothelium-derived nitric oxide: actions and properties. FASEB (Fed. Am. Soc. Exp. Biol.) J. 3:31-36.

6. Moncada, S., R. M. J. Palmer, and E. A. Higgs. 1991. Nitric oxide: physiology, pathology, and pharmacology. Pharmacol. Rev. 43:109-142.
7. Curran, R. D., T. R. Billar, D. J. Stuehr, K. Hoffman, and R. L. Simmons. 1989. Hepatocytes produce nitrogen oxides from $\mathrm{L}$-arginine in response to inflammatory products from Kupffer cells. J. Exp. Med. 170:1769-1774.

8. Mundel, P., S. Bachmann, M. Bader, A. Fischer, W. Kummer, B. Mayer, and W. Kriz. 1992. Expression of nitric oxide synthase in kidney macula densa cells. Kidney Int. 42:1017-1019.

9. Nelson, P. K., J. Brookins, and J. W. Fisher. 1983. Erythropoietic effects of prostacyclin $\left(\mathrm{PGI}_{2}\right.$ ) and its metabolite 6-keto-prostagrandin (PG) $\mathrm{E}_{1}$. J. Pharmacol. Exp. Ther. 226:493-499.

10. Mason-Garcia, M., J. Brookins, J. S. Powell, W. Lanhan, S. Blaisdell, L. Kaey, B. S. Beckman, and J. W. Fisher. 1990. Development of a radioimmunoassay (RIA) for erythropoietin (Ep) with an antibody to purified recombinant Ep (rEp). Kidney Int. 38:969-975.

11. Ueno, M., I. Rondon, B. Beckman, J. Brookins, J. Nakashima, F. E. Cole and J. W. Fisher. 1990. Increased secretion of erythropoietin in human renal carcinoma cells in response to hypoxia. Am. J. Physiol. 259(Cell Physiol. 28):C427-C431.

12. Menon, N. K., A. Wolf, M. Zehetgruber, and R. J. Bing. 1989. An improved chemiluminescence assay suggests non nitric oxide-mediated action of lysophosphatidylcholine and acetyl choline. Proc. Soc. Exp. Biol. Med. 191:316319.

13. Mulsch, A., A. Luckhoff, U. Pohl, R. Busse, and E. Bassenge. 1989. LY 83583 (6-anilino-5,8-quinolinedione) blocks nitrovasodilator-induced cyclic GMP increases and inhibition of platelet activation. Naunyn-Schmiedeberg's Arch. Pharmakol. 340:119-125.

14. Butt, E., M. van Bemmelin, L. Fischer, U. Walter, and B. Jastorff. 1990. Inhibition of cGMP-dependent protein kinase by (Rp)-guanosine 3',5'-monophosphorothioates. FEBS (Fed. Eur. Biochem. Soc.) Lett. 263:47-50.

15. Duncan, D. B. 1955. Multiple range and multiple F tests. Biometrics. 11:1-42.

16. Carmichael, J., W. G. DeGraff, A. F. Gazdar, J. D. Minna, and J. B. Mitchell. 1987. Evaluation of a tetrazolium-based semiautomated colorimetric assay: assessment of chemo sensitivity testing. Cancer Res. 47:936-942.

17. Bates, J. N., M. T. Baker, R. Guerra, Jr., and D. G. Harrison. 1991. Nitric oxide generation from nitroprusside by vascular tissue. Evidence that reduction of the nitroprusside anion and cyanide loss are required. Biochem. Pharmacol. 42(Suppl):S157-S165.

18. Gray, G. A., C. Schott, G. Julou-Schaeffer, I. Fleming, J. R. Paratt, and J. Stoclet. 1991. The effect of inhibitors of the L-arginine/nitric oxide pathway on endotoxin-induced loss of vascular responsiveness in anesthetized rats. $\mathrm{Br} . \mathrm{J}$. Pharmacol. 103:1218-1224.

19. Malgor, L. A., and J. W. Fisher. 1969. Antagonism of angiotensin by hydralazine on renal blood flow and erythropoietin production. Am. J. Physiol. 216:563-566.

20. Radermacher, J., B. Klanke, H. Schurek, H. F. Stolte, and J. C. Frolich. 1992. Importance of NO/EDRF for glomerular and tubular function: studies in the isolated perfused rat kidney. Kidney Int. 41:1549-1559.

21. Brezis, M., S. N. Heyman, D. Dinour, F. H. Epstein, and S. Rosen. 1991. Role of nitric oxide in renal medullary oxygenation: studies in isolated and intact rat kidneys. J. Clin. Invest. 88:390-395.

22. Goldberg, M. A., S. P. Dunning, and H. F. Bunn. 1988. Regulation of the erythropoietin gene: evidence that the oxygen sensor is a heme protein. Science (Wash. DC). 242:1412-1414.

23. Brune, B., K. U. Schmidt, and V. Ullrich. 1990. Activation of soluble guanylate cyclase by carbon monoxide and inhibition by superoxide anion. Eur. J. Biochem. 192:683-688.

24. Klatt, P., K. Schmidt, and B. Mayer. 1992. Brain nitric oxide synthase is a haemoprotein. Biochem. J. 288:15-17.

25. Hidaka, H., M. Inagaki, S. Kawamoto, and Y. Sasaki. 1984. Isoquinolinesulfonamide, novel and potent inhibitors of cyclic nucleotide dependent protein kinase and protein kinase C. Biochemistry. 23:5036-5041.

26. Butt, E., C. Nolte, S. Schultz, J. Beltman, J. A. Beavo, B. Jastorff, and U. Walter. 1992. Analysis of the functional role of cGMP-dependent protein kinase in intact human platelets using a specific activator 8-para-chlorophenylthiocGMP. Biochem. Pharmacol. 43:2591-2600.

27. Nakashima, J., J. Brookins, and J. W. Fisher. 1992. Characterization of erythropoietin production in a hepatocellular carcinoma cell line. J. Lab. Clin. Med. 119:306-314.

28. Goldberg, M. A., C. C. Gaut, and H. F. Bunn. 1991. Erythropoietin mRNA levels are governed by both the rate of gene transcription and posttranscriptional events. Blood. 77:271-277. 